\title{
Molecular Breeding and Variability Analysis of High Beta Carotene Introgressed $\mathrm{BC}_{1} \mathrm{~F}_{2}$ Line of Maize
}

\author{
Pitambara $^{1 *}$, P. Nagarajan ${ }^{2}$ and N. Senthil ${ }^{2}$ \\ ${ }^{1}$ Department of Agricultural Biotechnology, Anand Agricultural University, \\ Anand-388 110, Gujarat, India \\ ${ }^{2}$ Department of Agricultural Biotechnology, Tamil Nadu Agricultural University, \\ Coimbatore-641003, India \\ *Corresponding author
}

\section{A B S T R A C T}

\begin{tabular}{|l|}
\hline Ke y w or d s \\
Maize, Beta \\
carotene, \\
Variability, \\
Frequency \\
distribution. \\
\hline Article Info \\
\hline $\begin{array}{l}\text { Accepted: } \\
\text { 02 March } 2017 \\
\text { Available Online: } \\
\text { 10 April 2017 }\end{array}$ \\
\hline
\end{tabular}

\section{Introduction}

Maize (Zea mays L.) is the world's most important cereal crop of global importance after wheat. Versatile utility of corn as food and feed enhances the area under production and the productivity day by day (Netravati et al., 2013). Babu et al., (2012) opined that in latter generations.
Among all the micro nutrient deficiencies, World Health Organization (WHO) had identified Vitamin A deficiency as the more dangerous and widespread micronutrient deficiencies in the world. In order to address this global problem, biofortification of Maize is considered to be a cost effective and sustainable approach. The present study was carried out to raise and identify high $\beta$ - carotene maize lines of $\mathrm{BC}_{1} \mathrm{~F}_{2}$ (UMI $1200 \times \mathrm{HP} 467-15$ )C15-S79 population by phenotyping using HPLC along with genotyping of crtRB1 allele. The randomly selected 10 seeds of selected $\mathrm{BC}_{1} \mathrm{~F}_{2}$ cob were analyzed for $\beta$-carotene content through HPLC and the results showed confirmation of improvement in $\beta$-carotene content of $3.00 \mu \mathrm{g} / \mathrm{g}$ respectively. The $c r t R B 1$ allele polymorphism in $\mathrm{BC}_{1} \mathrm{~F}_{2}(\mathrm{UMI} 1200 \times \mathrm{HP} 467-15)-$ C15-S79 population of the two crosses revealed that the progenies showed segregation distortion (SD) populations, indicating that the favorable allele is under-represented in the population. The variability studies in $\mathrm{BC}_{1} \mathrm{~F}_{2}$ population revealed that, low and moderate GCV and PCV was found for all traits which gives an indication of justifiable variability among the genotypes with respect to these characters and therefore gives scope for improvement of these traits in future generations through selection. The PCV was higher than the corresponding GCV for most of the traits under study which results in high heritability. The heritability estimates of $\mathrm{BC}_{1} \mathrm{~F}_{2}$ generation were found to be highest for plant height. Frequency distribution study of $\mathrm{BC}_{1} \mathrm{~F}_{2}$ population states that for the traits like plant height, ear height and 100 kernel weight, most of the progenies exhibited the values same as or near to recurrent parent. $\mathrm{BC}_{1} \mathrm{~F}_{2}$ population, showed positive skewness for days to 50 per cent tasseling, plant height and ear height while negative skewness was observed for leaf length, days to 50 per cent silking and 100 kernel weight. Negative kurtosis was observed for all the six traits, in $\mathrm{BC}_{1} \mathrm{~F}_{2}$ population. The study indicated that it is possible to develop a high $\beta$-carotene inbred with genetic identity closer to that of the recurrent parent 
corn flour. With all its higher nutritive value maize is deficit in beta carotene (Figure 1). Enriching corn with vitamin A will serve and assure the human population feeding on maize with enriched nutritive factor the solution for major diseases and eye blindness caused by vitamin A deficiency. Markers can be used in the context of Marker-Assisted Back Crossing (MABC) to either control the target gene (foreground selection) or to accelerate the reconstruction of the recurrent parent genotype (background selection). Maize breeders try to combine the nutritional quality traits with yield to produce nutritive inbreds. Selection of favorable gene alleles with inexpensive molecular markers will enable breeders to produce more effectively maize grain with higher provitamin A levels.

Vallabhaneni et al., (2009) and Yan et al., (2010) expressed that the crtRB1 specifically controls hydroxylation of $\beta$-carotene (BC) to $\beta$ - crypotozanthin $(\mathrm{BCX})$ in maize endosperm tissues, and its alleles with reduced hydroxylation activity which were associated with increased $\mathrm{BC}$ content and $\mathrm{BC}$ to $\mathrm{BCX}$ ratio (Figure 2). Yan et al., (2010) confirmed that Zea mays crtRBl gene is an important gene associated with $\beta$-carotene metabolism in maize kernels and identified that three different polymorphisms in crtRB1 gene viz., 5'TE, InDel4 and 3'TE, are responsible for significant variation of $\beta$-carotene concentration in kernels. Owing to the polymorphism of $3^{\text {'TE }}$ (that spans the $6^{\text {th }}$ exon and the 3' UTR) (Yan et al., 2010 and Vignesh et al., 2012), the crtRB1 gene exists in three allelic states; 3'TE allele 1 (without insertion), 3'TE allele 2 (with 325 bp insertion), and 3'TE allele 3 (with $1250 \mathrm{bp}$ insertion) (Figure 3). The 3'TE allele hierarchy according to kernel $\beta$-carotene content is $1>3>2$, which means allele 1 is more favourable than the alleles 2 and 3 for higher $\beta$-carotene accumulation in kernels and hence allele 1 is termed as favourable allele and alleles 2 and 3 are termed as unfavourable alleles (Yan et al., 2010).

The success of any crop improvement programme not only dependent on the amount of genetic variability present in the population but also on the extent to which it is heritable, which sets the limit of progress that could be achieved through selection (Wang et al., 2011). Genetic variability for agronomic characters therefore is a key component of breeding programmes for broadening the gene pool of crops (Ahmad et al., 2011). The phenotypic coefficient of variation is the observable variation present in a character or in a population; it includes both genotypic and environmental components of variation and as a result, its magnitude differs under different environmental conditions. The genotypic coefficient of variation on the other hand, is the component of variation which is due to genotypic differences among individuals within a population and is the main concern of plant breeders.

Researchers have reported significant amount of variability in different maize populations including top-crosses and open pollinated varieties (Sampoux et al., 1989). Heritability is a measure of the phenotypic variance attributable to genetic causes and has predictive function in plant breeding. It provides information on the extent to which a particular morphogenetic character could be transmitted to successive generations. Knowledge of heritability influences the choice of selection procedures used by the plant breeder to decide which selection methods would be most useful to improve the character, to predict gain from selection and to determine the relative importance of genetic effects (Laghari et al., 2010).

Keeping the above in mind, the present study deals with following objectives (Figure 4): 
Phenotyping of high $\beta$-carotene (UMI $1200 \times$ HP 467-15) $\mathrm{BC}_{1} \mathrm{~F}_{2}$ progenies through HPLC and Identification of favourable crtRB1 allele in $\mathrm{BC}_{1} \mathrm{~F}_{2}$ population.

Variability and frequency distribution analysis of $\mathrm{BC}_{1} \mathrm{~F}_{2}$ population.

Forwarding selected selfed progenies to generate further $\mathrm{BC}_{1} \mathrm{~F}_{3}$ generation

\section{Materials and Methods}

$\mathrm{BC}_{1} \mathrm{~F}_{1}$ population were raised along with the parent UMI 1200 (Pollen source for backcrossing) in summer, 2013. Screening of $\mathrm{BC}_{1} \mathrm{~F}_{1}$ plants and its scoring was done. Selfing of progenies were made to produce $\mathrm{BC}_{1} \mathrm{~F}_{2}$ generation seeds. In the present study $\mathrm{BC}_{1} \mathrm{~F}_{2}$ progenies so produced were analyzed for $\beta$ carotene content by HPLC. The selected progenies which were having high $\beta$-carotene were raised along with recurrent parents separately in Rabi, 2013 at the Eastern Block, TNAU, Coimbatore with two staggered sowings at 3 and 5 days interval in order to achieve synchronized flowering of parents for hybridization. All the cultural operations were carried out as per the recommendations of crop production guide of Tamil Nadu.

\section{Evaluation of $\beta$-carotene content}

The randomly selected 10 seeds of selected $\mathrm{BC}_{1} \mathrm{~F}_{2}$ cobs were analyzed for $\beta$-carotene content through HPLC for confirmation of improvement in $\beta$-carotene content.

\section{Scoring of progenies for crtRB1 allelic variation}

Seedlings were grown in the field for 3 weeks after which fresh leaf tissue of 5-6 seedlings of each inbred line was harvested and stored in Eppendorf tubes at $-80^{\circ} \mathrm{C}$ for total genomic DNA extraction using CTAB method (Dellaporta et al., 1983). The quality and quantity of DNA was determined by spectrophotometer absorbance at $260 \mathrm{~nm}$. Polymerase chain reaction was performed using crtRB1 3'TE gene-specific primers. The segregation pattern of crtRB 1 alleles in all $\mathrm{BC}_{1} \mathrm{~F}_{2}$ segregating progenies were scored in the following pattern. The individuals showing the banding pattern similar to the parent UMI 1200 with the allele size of $296+$ 1221 were scored as "AA", the plants with the alleles similar to the parent, HP 467-15 (543 bp allele) were scored as "BB" and the heterozygote's were scored as "AB" $(296+543$ allele size) and tested for their significance using Chi- square test.

\section{Chi -square goodness of fit}

The fitness was calculated as below

$$
x^{2}=\sum
$$$$
(\text { Observed - expected })^{2}
$$$$
\text { Expected }
$$

The significance is tested by comparing the calculated value and table value and the results were reported as below at 5\% level of significance.

Null hypothesis: There is no significant difference between expected ratio and observed ratio

Alternate hypothesis: There is significant difference between expected ratios

\section{Development of $\mathrm{BC}_{1} \mathrm{~F}_{3}$ generation}

The $\mathrm{BC}_{1} \mathrm{~F}_{2}$ progenies which were confirmed for high $\beta$-carotene content using HPLC and molecular markers were forwarded to develop further generation. The selected $\mathrm{BC}_{1} \mathrm{~F}_{2}$ population was selfed. Selfing was carried out adopting tassel bag method to generate $\mathrm{BC}_{1} \mathrm{~F}_{3}$ which were sown in summer, 2014.

\section{Evaluation of agronomical traits}

The back cross progenies were evaluated for the following quantitative characters for their 
per se performance. During crop growth, observations on leaf length, days to 50 per cent tasseling and silking were observed.

Before harvest, the tassel length and plant height were recorded. After harvest, 100 kernel weights were recorded. These observations were used for variability analysis.

\section{Variability studies in $\mathrm{BC}_{1} \mathrm{~F}_{2}$ populations}

The $\mathrm{BC}_{1} \mathrm{~F}_{2}$ populations were evaluated for 6 quantitative morphological characters. The data was utilized for variability analysis. The various genetic parameters like Phenotypic Coefficients of Variability (PCV), Genotypic Coefficients of Variability GCV, Heritability $\left(\mathrm{h}^{2}\right)$, Genetic Advance (GA) and Genetic Advance as per cent Mean (GAM), were worked out for the progenies by adopting the formulae given by Johnson et al., (1955).

The phenotypic data of $\mathrm{BC}_{1} \mathrm{~F}_{2}$ progenies along with the parents were utilized for studying the frequency distribution, skewness and kurtosis.

\section{Phenotypic and genotypic variance}

The average variance observed in the parent UMI 1200 and HP 467-15 were considered as environmental variance.

The genotypic variance of each generation was estimated by subtracting the estimated environmental variance from the phenotypic variance as follows.

\section{Phenotypic and genotypic coefficients of variability}

Based on the calculated Phenotypic and genotypic variance for $\mathrm{BC}_{1} \mathrm{~F}_{2}$ generation $\mathrm{PCV}$ and GCV were calculated and scored as in table 1 (Sivasubramanian and Madhava Menon, 1973).

\section{Heritability $\left(\mathbf{h}^{2}\right)$}

Heritability $\left(\mathrm{h}^{2}\right)$ estimate in broad sense at five per cent selection intensity were estimated and expressed in percentage.

$\mathrm{h}^{2}{ }_{\text {(broad sense) }}=\sigma_{\mathrm{g}}^{2} / \sigma_{\mathrm{p}}^{2} \times 100$

$\sigma_{\mathrm{g}}{ }^{2} \quad=$ genotypic variance of the

population

$\sigma_{\mathrm{p}}^{2}=$ Phenotypic variance of population

The heritability per cent was categorized as below adopted by Robinson et al., (1949).

\begin{tabular}{|l|l|}
\hline Heritability in per cent & Category \\
\hline$<30$ & Low \\
$31-60$ & Medium \\
$>60$ & High \\
\hline
\end{tabular}

\section{Genetic advance (GA)}

Genetic advance was estimated by the method formulated by Johnson et al., (1955).

Genetic advance $=\mathrm{kx} \mathrm{h}^{2} \mathrm{x} \sigma \mathrm{p}$

Where,

$\mathrm{h}^{2}=$ Heritability in broad sense

$\sigma \mathrm{p}=$ Phenotypic standard deviation

$\mathrm{k}=$ Selection differential (at $5 \%$ selection intensity) (i.e.) 2.06 (Falconer, 1960)

Genetic advance as per cent of mean (GAM)

The genetic advance as per cent of mean was categorized as suggested by Johnson et al., (1955).

GA as per cent of mean $=$

$\frac{\text { Genetic advance }}{\text { Grand mean }} \times 100$


GA was categorized as:

\begin{tabular}{|l|l|}
\hline GA per cent value & Category \\
\hline$<10$ per cent & Low \\
$10-20$ per cent & Moderate \\
$>20$ per cent & High \\
\hline
\end{tabular}

\section{Frequency distribution}

The phenotypic data of progenies along with the parents were utilized for studying the frequency distribution for leaf length, days to 50 per cent tasseling, days to 50 per cent silking, plant height, ear height and hundred kernel weight. It was calculated by classification into different classes at regular class intervals and the population distribution was obtained pictographically for all the characters under study in which the number of progenies resembling the parental range could be identified.

\section{Skewness and Kurtosis}

These were calculated using the frequency distribution of the characters mentioned.

$\beta_{1}=$ Skewness

If, $\quad \beta_{1}>0$, then positively skewed $\beta_{1}<0$, then negatively skewed $\beta_{1}=0$, then symmetric distribution

$\beta_{2}=$ Kurtosis

If, $\quad \beta_{2}>1$, then leptokurtic

$\beta_{2}<1$, then platykurtic

$\beta_{2}=0$, then mesokurtic

$$
\begin{aligned}
& \beta_{1}=\frac{\mu_{8}^{2}}{\mu_{2}^{2}} \\
& \beta_{2}=\frac{\mu_{4}^{2}}{\mu_{2}^{2}}
\end{aligned}
$$

Where,

$$
\mu_{2=\frac{1}{N}}^{2} \Sigma \mathrm{f}(\mathrm{Xi}-\mathrm{X})^{2}
$$

Where,

$$
\begin{aligned}
& \mu_{3=\frac{1}{N} \Sigma_{f i}(X i-R)^{g}}^{2} \\
& \mu_{4=\frac{1}{N} \sum_{f i}(X i-R)^{4}}^{2}
\end{aligned}
$$

$\mathrm{X}_{\mathrm{i}}$ is the individual observation

$X$ is the mean of the character under observation and

$\mathrm{N}$ is the number of observations

\section{Statistical analysis}

For the quantitative morphological characters descriptive statistics were carried out using XLSTAT software to estimate mean, range, standard deviation and variance. The Chisquare goodness of fit was estimated using XLSTAT software. The phenotypic data of $\mathrm{BC}_{2} \mathrm{~F}_{1}$ and $\mathrm{BC}_{1} \mathrm{~F}_{2}$ progenies were subjected for variability analysis using XLSTAT software and frequency distribution, skewness and kurtosis by SPSS.16.

\section{Results and Discussion}

The present investigation was carried out to develop high $\beta$-carotene maize by introgressing crtRB1 allele through marker assisted backcross breeding. $\mathrm{BC}_{1} \mathrm{~F}_{2}$ progenies were analyzed for $\beta$-carotene content by HPLC. The selected progenies identified to contain high $\beta$-carotene by HPLC profiling were raised and genotyping of $c r t R B 1$ allele was done. Based on marker data analysis plants having favourable allele 1(543bp) were selected for selfing to developBC $\mathrm{C}_{1} \mathrm{~F}_{3}$ generation seeds.

\section{Estimation of $\beta$-carotene content $\mathbf{B C}_{1} \mathbf{F}_{2}$ progenies}

The randomly selected 10 seeds of selected $\mathrm{BC}_{1} \mathrm{~F}_{2}$ (Plate 1) cobs were analyzed for $\beta$ carotene content through HPLC for confirmation of improvement in $\beta$-carotene content. The results revealed that $\beta$-carotene content of $\mathrm{BC}_{1} \mathrm{~F}_{2}(\mathrm{UMI} 1200 \times \mathrm{HP} 467-15)$ - 
C15-S79) was 3.00 $\mu \mathrm{g} / \mathrm{g}$ (Figure 8) and the progeny was forwarded to develop $\mathrm{BC}_{1} \mathrm{~F}_{2}$ population.

Foreground marker screening in (UMI $1200 \times$ HP467-15)-C15-S79 $\quad \mathrm{BC}_{1} \mathrm{~F}_{2}$ population

Among the 100 plants of (UMI $1200 \times$ HP467-15)-C15-S79 $\mathrm{BC}_{1} \mathrm{~F}_{2}$ population, 52 progenies showed both parent's alleles 'AB' (Heterozygotes with allele size of $296+543$ bp), 18 progenies showed 'B' alleles (Allele size of $543 \mathrm{bp}$ ) and 30 progenies showed 'A' alleles (Allele size of 296 bp). Progenies showing homozygous to favourable allele1 (546bp) viz., 'BB' is selected for selfing to develop $\mathrm{BC}_{1} \mathrm{~F}_{3}$ generation seeds (Figure 5).

\section{Chi -square goodness of fit}

The Chi-square test for goodness of fit was calculated for allele frequency (Table 2). The progenies showed deviation in expected segregating ratio (1:2: 1) with respect the crtRB1 gene specific marker. In $F_{2}$ population, segregation disorder (SD) was skewed towards the unfavourable homozygous and/or heterozygote allele and the favourable allele was under-represented in the $\mathrm{BC}_{1} \mathrm{~F}_{2}$ population.

The Chi-Square test results revealed that the progenies showed deviation in expected segregating ratio of $\mathrm{BC}_{1} \mathrm{~F}_{2}$ (1: 2:1) populations of the cross UMI $1200 \times$ HP467-15 with respect the crtRB1 gene specific marker, where segregation disorder(SD) was observed for $c r t \mathrm{RB} 1$ in $\mathrm{BC}_{1} \mathrm{~F}_{2}$ populations. In $\mathrm{BC}_{1} \mathrm{~F}_{2}$ population, segregation disorder (SD) was skewed toward the unfavourable homozygous allele and the favorable allele was underrepresented. The present results were in confirmation with the earlier reports. Lu et al., (2002) opined that the observation of segregation disorder (SD) for $L c y E$ in all eight and for $c r t R B 1$ in five of the eight digenic $\mathrm{F}_{2}$ populations was consistent with frequent observation of SD in maize and presence of many segregation distortion regions (SDRs) throughout the maize genome. Segregation distortion (SD) in maize could be due to the presence of gametophytic factors (ga) (Mangelsdorf and Jones 1926; Neuffer et al., 1997) or to naturally occurring gene mutants like dek (defective kernel), ms (male sterile) and emb (embryo-specific mutation) (Neuffer et al., 1997).

\section{Development of $\mathrm{BC}_{1} \mathrm{~F}_{3}$ progenies}

The individuals possessing the crtRB 1 loci in homozygous condition (BB) were selfed to produce $\mathrm{BC}_{1} \mathrm{~F}_{3}$ generation (UMI $1200 \times \mathrm{HP}$ 467-15)-C15-S79-S7). The $\beta$-carotene content of $\mathrm{BC}_{1} \mathrm{~F}_{3}$ progenies so produced will be estimated and then raised during Summer, 2014.

Table.1 PCV and GCV of $\mathrm{BC}_{1} \mathrm{~F}_{2}$

\begin{tabular}{|c|c|c|}
\hline Phenotypic Coefficient of Variation (\%) (PCV) & \multicolumn{2}{|c|}{$\frac{\sqrt{\text { Phenotypic variance }}}{\text { Grand mean }} \times 100$} \\
\hline Genotypic Coefficient of Variation (\%) (GCV) & $\frac{\sqrt{\text { Genotypic variance }}}{\text { Grand mean }}$ & $\times 100$ \\
\hline \multirow[t]{4}{*}{ Scoring for PCV and GCV variability } & PCV and GCV & Category \\
\hline & $<10$ per cent & Low \\
\hline & $10-20$ per cent & Moderate \\
\hline & $>20$ per cent & High \\
\hline
\end{tabular}


Table.2 Chi-square goodness of fit for $\mathrm{BC}_{1} \mathrm{~F}_{2}$ segregating population of (UMI $1200 \times$ HP467-15)-C15-S79

\begin{tabular}{|c|c|c|c|c|c|c|}
\hline \multirow[b]{2}{*}{ Population } & \multirow[b]{2}{*}{ Marker } & \multirow{2}{*}{$\begin{array}{l}\text { Total } \\
\text { No. of } \\
\text { plants }\end{array}$} & \multicolumn{3}{|c|}{ Observed values } & \multirow[b]{2}{*}{$x^{2}$} \\
\hline & & & $\begin{array}{c}\text { Heterozygous } \\
\text { (AB) }\end{array}$ & $\begin{array}{l}\text { Homozygous } \\
\text { (AA) }\end{array}$ & $\begin{array}{l}\text { Homozygous } \\
\text { (BB) }\end{array}$ & \\
\hline $\begin{array}{l}\text { UMI } 1200 \times \\
\text { HP467-15 }\end{array}$ & crtRB1 & 100 & 52 & 30 & 18 & 27.04 \\
\hline
\end{tabular}

The table value of $\varkappa^{2}(\mathrm{df}=1)$ at $5 \%$ level is 5.91. The calculated value is more than calculated value. There is deviation between expected ratio and observed ratio.

Table.3 Descriptive statistics of $\mathrm{BC}_{1} \mathrm{~F}_{2}$ segregating generation

(UMI $1200 \times$ HP 467-15)-S15-S79

\begin{tabular}{|l|c|c|c|c|c|c|}
\hline \multirow{2}{*}{ Parameters } & \multicolumn{2}{|c|}{ Parental lines } & \multirow{2}{*}{ Mean } & Range & $\begin{array}{c}\text { Standard } \\
\text { deviation }\end{array}$ & Variance \\
\cline { 2 - 6 } & $\begin{array}{l}\text { UMI } \\
\mathbf{1 2 0 0}\end{array}$ & HP467-15 & & & & \\
\hline Leaf length (cm) & 51.6 & 42.3 & 53.54 & $40-59$ & 5.35 & 28.64 \\
\hline $\begin{array}{l}50 \% \text { tasseling } \\
\text { (days) }\end{array}$ & 60 & 56 & 59 & $54-64$ & 3.6 & 12.99 \\
\hline $50 \%$ silking (days) & 63 & 59 & 61 & $57-64$ & 2.69 & 7.42 \\
\hline Plant height (cm) & 128 & 108.8 & 132.61 & $105-138$ & 6.59 & 44.5 \\
\hline Ear height (cm) & 64.2 & 45 & 69 & $44-74$ & 5.6 & 31 \\
\hline $\begin{array}{l}100 \text { kernel weight } \\
(\mathrm{g})\end{array}$ & 26 & 22.9 & 28.2 & $20-30$ & 2.48 & 6.15 \\
\hline
\end{tabular}

Table.4 Variability analysis in $\mathrm{BC}_{1} \mathrm{~F}_{2}$ population of (UMI $\left.1200 \times \mathrm{HP} 467-15\right)-\mathrm{S} 15-\mathrm{S} 79$

\begin{tabular}{|l|c|c|c|c|c|}
\hline \multicolumn{1}{|c|}{ Parameters } & PCV \% & GCV \% & $\mathbf{h}^{\mathbf{2}} \boldsymbol{\%}$ & GA & GAM \\
\hline Leaf length (cm) & 11.73 & 10.2 & 64.40 & 7.8 & 15.5 \\
\hline 50\% tasseling (days) & 4.40 & 4.36 & 54.3 & 5.01 & 8.88 \\
\hline 50\% silking (days) & 3.2 & 2.42 & 55.53 & 2.20 & 3.72 \\
\hline Plant height (cm) & 6.03 & 5.93 & 97.05 & 14.75 & 12.04 \\
\hline Ear height (cm) & 11.91 & 4.30 & 66.07 & 1.91 & 3.21 \\
\hline 100 kernel weight (g) & 8.38 & 7.2 & 71.8 & 0.34 & 1.2 \\
\hline
\end{tabular}

GCV, PCV and GA as mean: Low $-<10 \%$; Moderate $10-20 \%$; High $>20 \%$

$\mathrm{h}^{2}:$ Low - $30 \%$; Medium- $31-60 \%$; High - > $60 \%$

(PCV -Phenotypic coefficient of variability, GCV- Genotypic coefficient of variability, h2 -Heritability, GAGenetic advance and GAM - Genetic advance as per cent mean) 
Table.5 Skewness and kurtosis variation in $\mathrm{BC}_{1} \mathrm{~F}_{2}$ Population (UMI $1200 \times$ HP 467-15)-S15-S79

\begin{tabular}{|l|c|c|}
\hline \multirow{2}{*}{\multicolumn{1}{|c|}{ Traits }} & Skewness & Kurtosis \\
\cline { 2 - 3 } & $\mathbf{B C}_{\mathbf{1}} \mathbf{F}_{\mathbf{2}}$ & $\mathbf{B C}_{\mathbf{1}} \mathbf{F}_{\mathbf{2}}$ \\
\hline Leaf length (cm) & -0.04 & -1.32 \\
\hline 50\% tasseling (days) & 0.41 & -0.6 \\
\hline 50\% silking (days) & -0.12 & -0.75 \\
\hline Plant height (cm) & 0.06 & -1.44 \\
\hline Ear height (cm) & 0.04 & -0.80 \\
\hline 100 kernel weight $(\mathrm{g})$ & -0.026 & -1.05 \\
\hline
\end{tabular}

$(<0)$ - Negatively skewed; (>0) - Positively skewed; (0) - Normal distribution

Table.6 HPLC analysis of $\beta$-carotene content of parents (UMI 1200 and $\mathrm{HP} 467-15)$ and selected $\mathrm{BC}_{1} \mathrm{~F}_{2}$ progeny

\begin{tabular}{|l|l|l|}
\hline \multicolumn{1}{|c|}{ Parents/progenies } & \multicolumn{1}{|c|}{ Pedigree } & \multicolumn{1}{|c|}{$\boldsymbol{\beta}$-carotene $(\boldsymbol{\mu g} / \mathbf{g})$} \\
\hline Recurrent & UMI1200 & 1.16 \\
\hline Donor & HP467-15 & 5.1 \\
\hline $\mathrm{BC}_{1} \mathrm{~F}_{2}$ & (UMI1200×HP467-15)-C15-S79 & 3.00 \\
\hline
\end{tabular}

Plate.1 Variability in cob characters

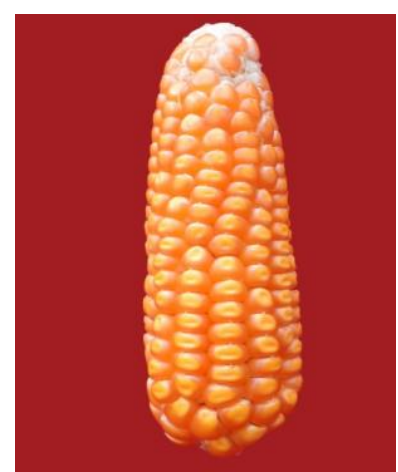

UMI 1200 (Recurrent parent)

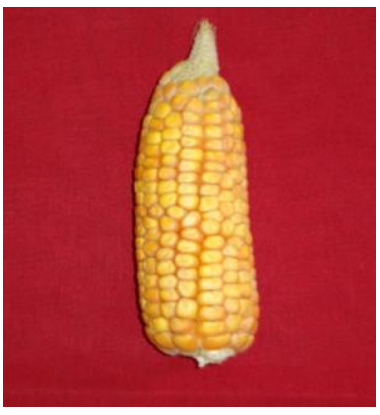

BC1F2

[Pedigree: (UMI1200×HP467-15)-C15-S79]

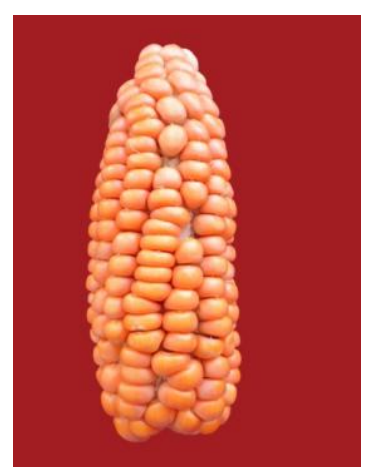

HP467-15 (Donor parent)

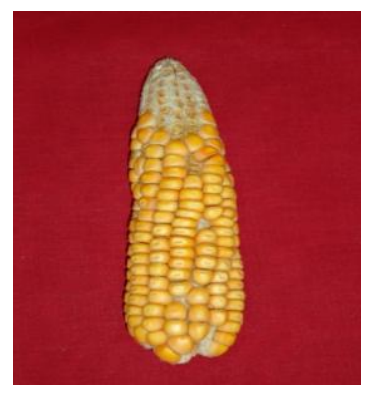

BC1F3

[Pedigree: (UMI1200×HP467-15)-C15-S79-S7] 
Figure.1 Structure of $\beta$-carotene

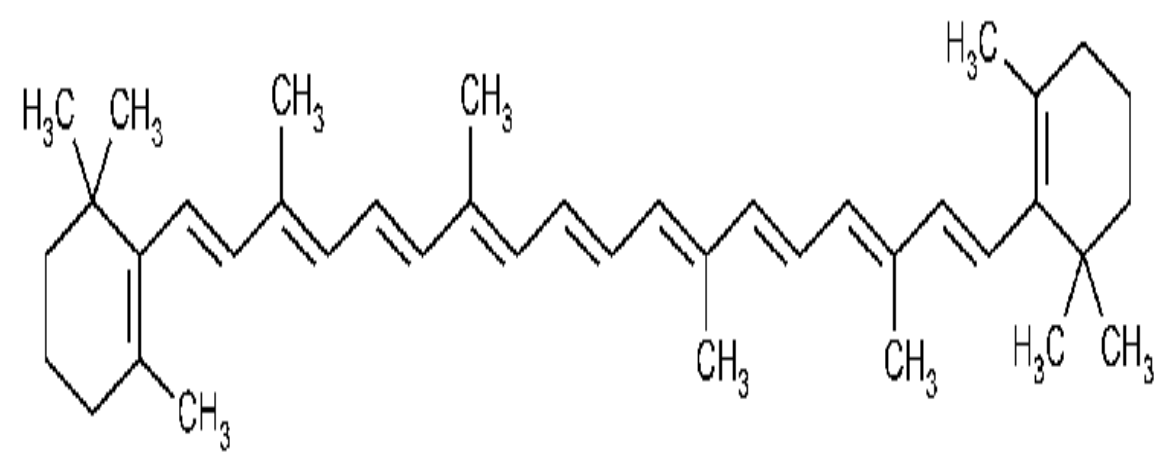

Figure.2 Carotenoid biosynthetic pathway in plants

Geranylgeranyl diphosphate
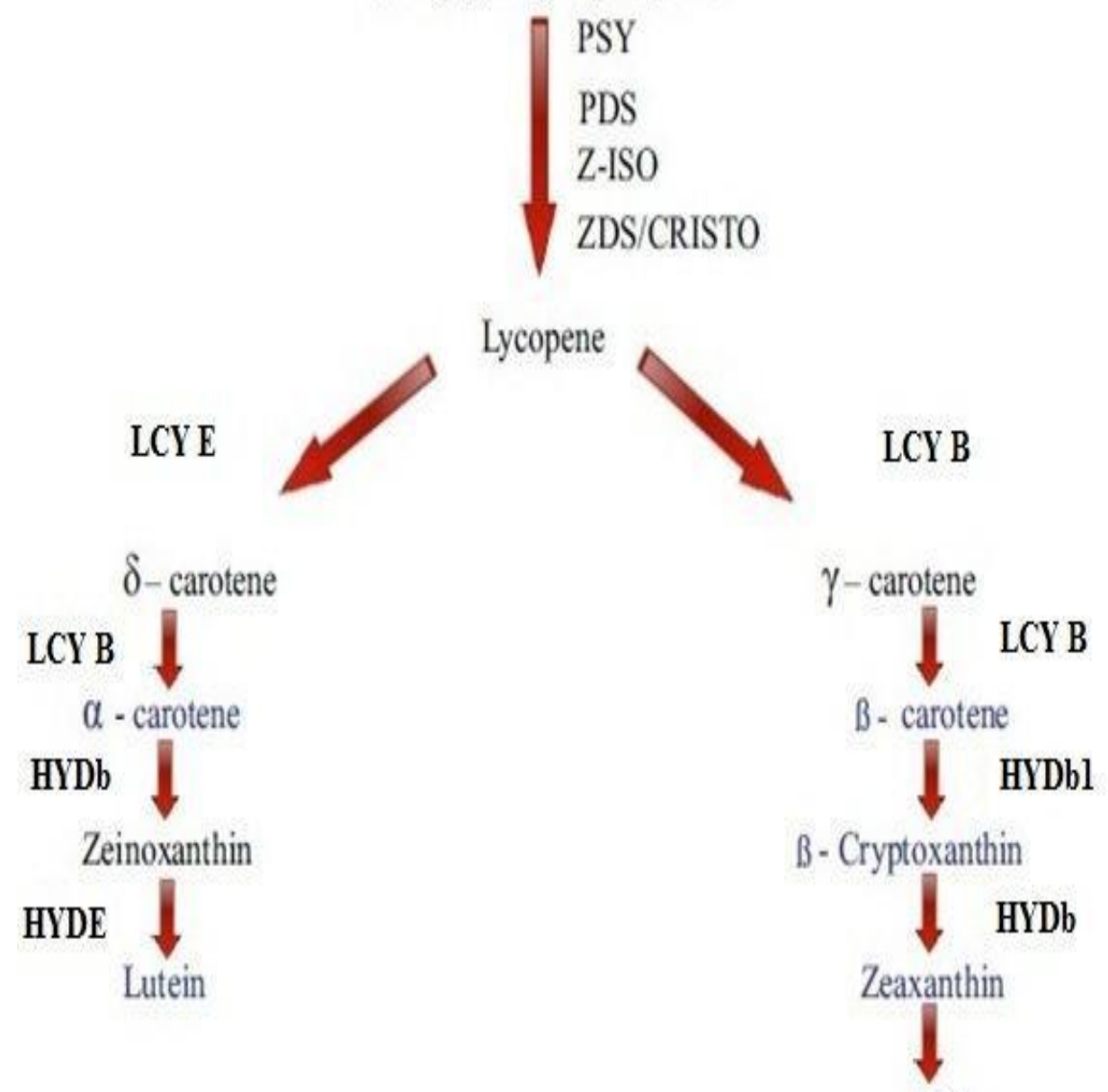

$\mathrm{ABA}$ 
Figure.3 Genetic variation at crtRB1 3'TE (Modified from Yan et al., 2010). The genetic variation due to insertions at "3'TE" (a polymorphic site of the crtRB1 gene results three alleles that are associated with variation in $\beta$-carotene accumulation in the kernel. Allele 1 is without insertion and a PCR of this allele with the indicated primer set results in an amplicon of size $543 \mathrm{bp}$. Allele 2 has a 325bp insertion and a PCR of this allele with the indicated primer sets results in an amplicon of size $296+875 \mathrm{bp}$. Allele 3 has a 1250bp insertion and a PCR of this allele with the indicated primer sets results in an amplicon of size 296+1221+1800 (However, the largest amplicon (1800 bp) amplified by the primers $65 \mathrm{~F}$ and 66R was usually weak or not amplified). Of the three alleles of 3 'TE, allele 1 is known as a favorable allele, for it is associated with the enhancement of $\beta$-carotene concentration in the maize grain.

\section{Three 3'TE alleles of crtRB1 gene}

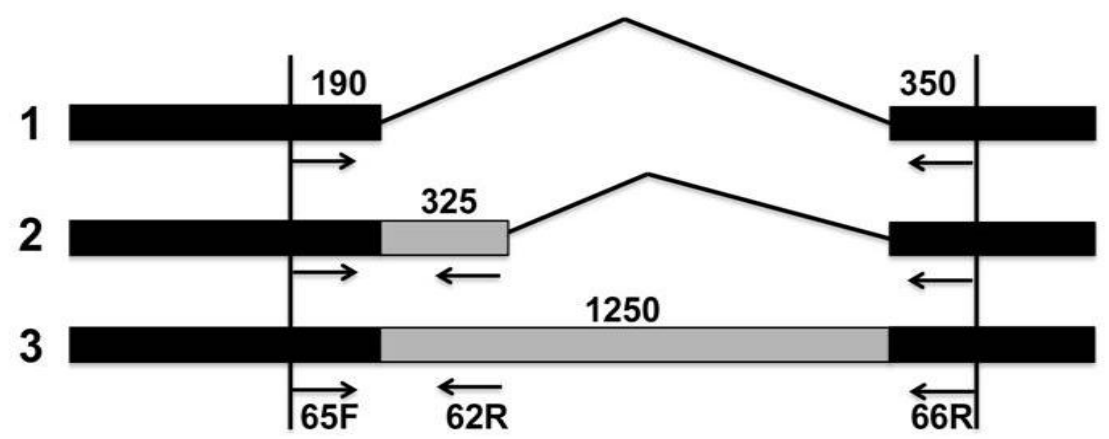

Figure.4 Breeding programme for introgression of $\operatorname{crtRB} 1$ allele into UMI 1200 by marker assisted selection. The populations used (i.e., P1 and P2) or developed (i.e., F1 and BC1F1) in the previous study are shown in black fonts and the populations used (i.e., BC1F2) or developed (i.e., $\mathrm{BC} 1 \mathrm{~F} 3$,) in the present study are shown in red fonts

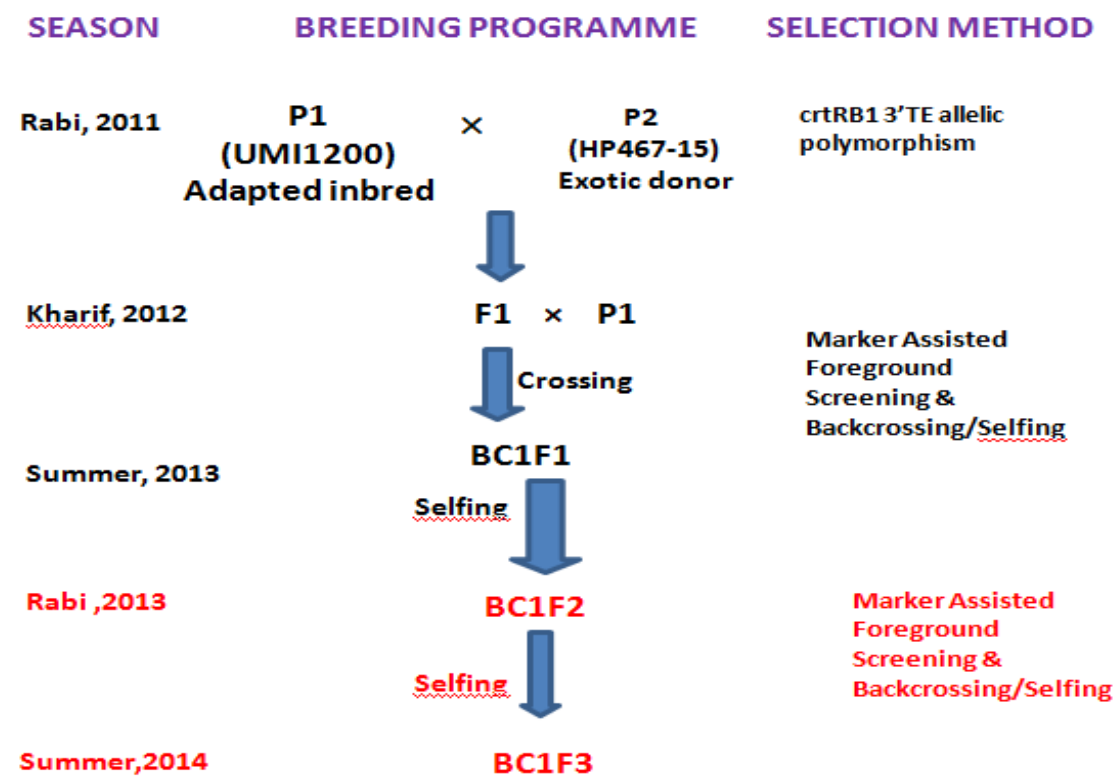


Figure.5 Screening of foreground marker (crtRB1 3'TE alleles) in BC1F2 population [pedigree: (UMI1200×HP467-15)-S15-S79] L denotes the marker lane. P1 and P2 denote the parents UMI 1200 and HP467-15 respectively. The numbers above the lanes refer to the progenies analyzed in $\mathrm{BC} 1 \mathrm{~F} 2$ population (numbers in red are selected progenies selfed)
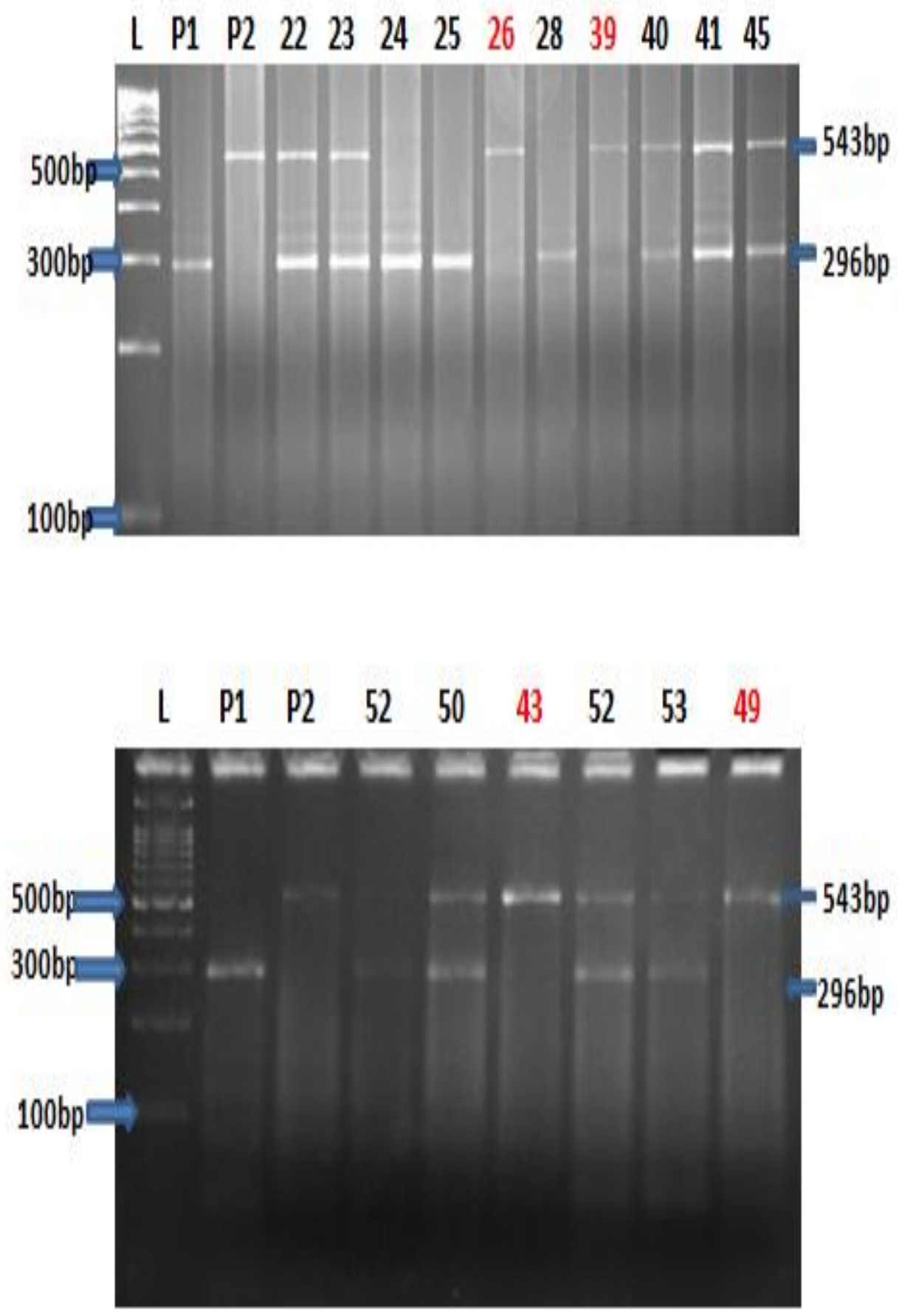
Figure.6 Frequency distribution curve for morphological characters of $\mathrm{BC}_{1} \mathrm{~F}_{2}$ population

[Pedigree: (UMI $1200 \times$ HP 467-15)-S15-S79]
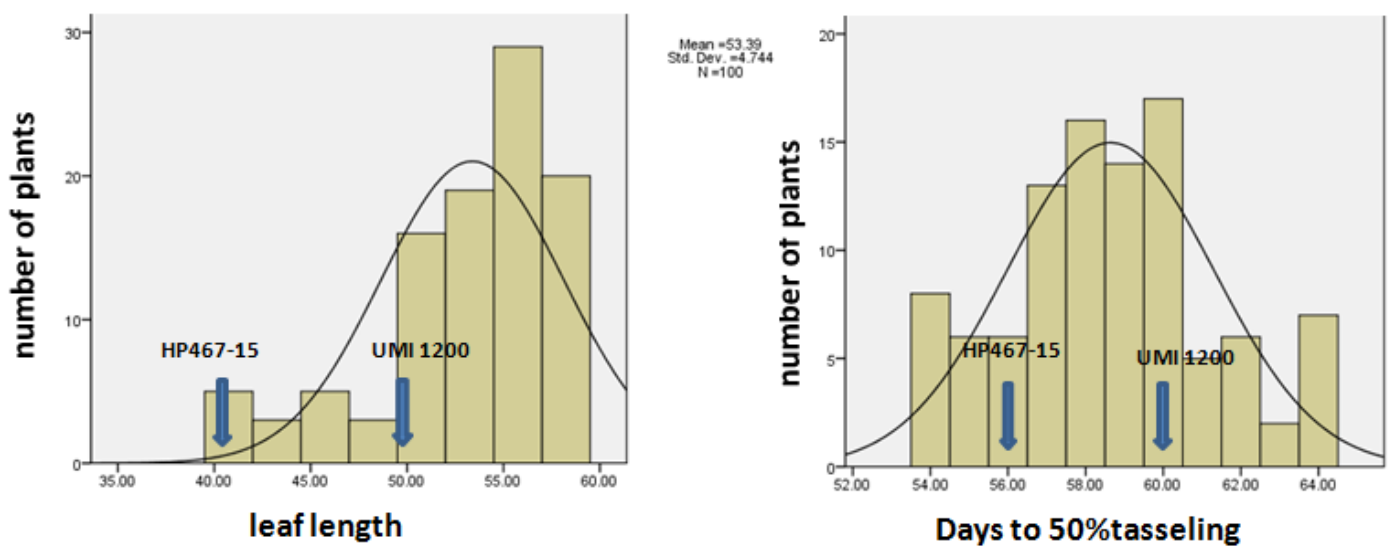

Mean $=58.64$
Std. Dev $=2.665$
$N=100$
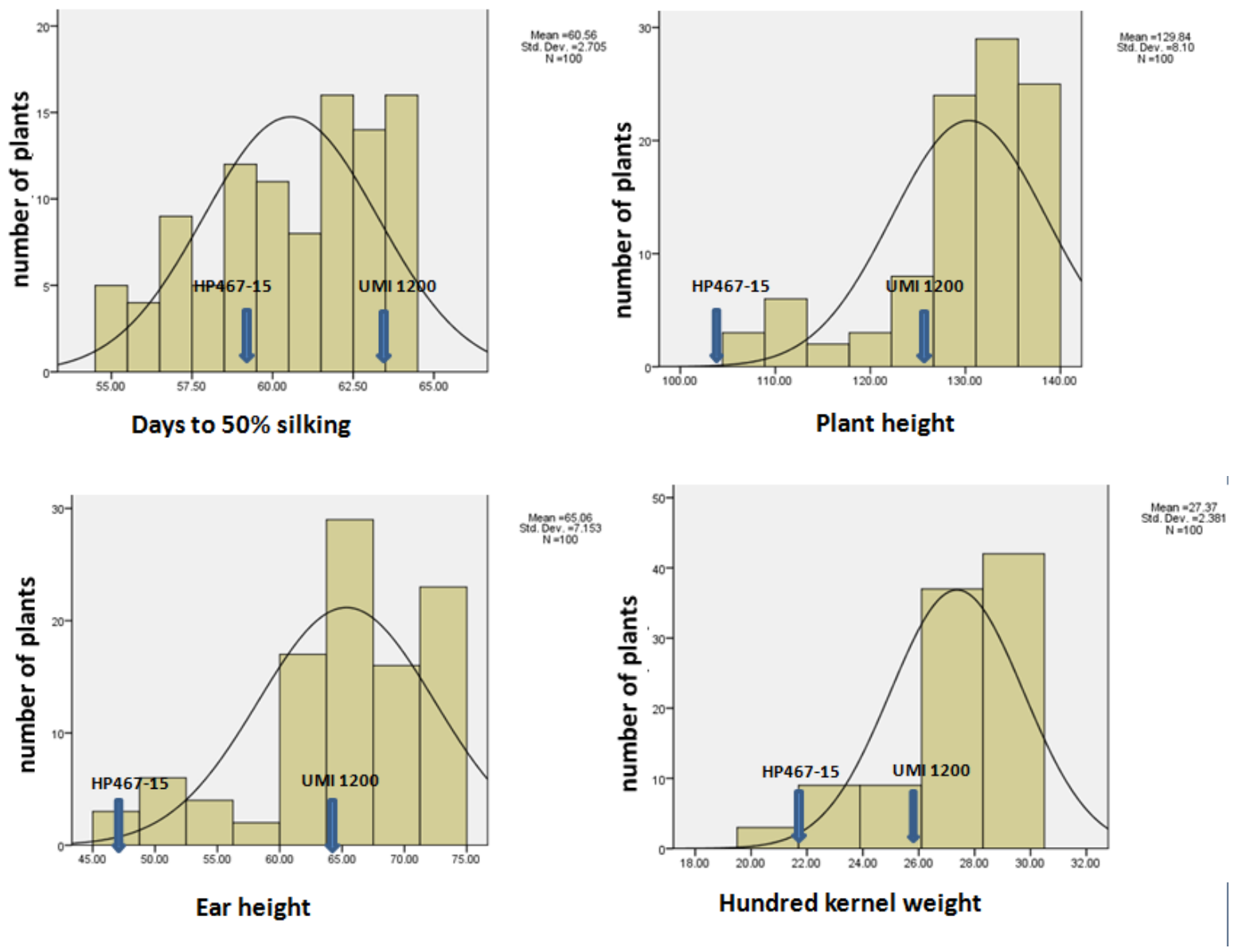
Figure.7 HPLC Chromatogram for $\beta$-carotene content of Donor (HP467-15) and Recurrent (UMI1200) parents

HP 467 -15

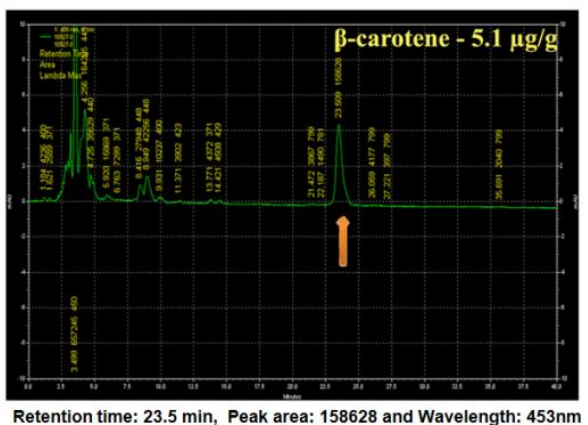

UMI 1200

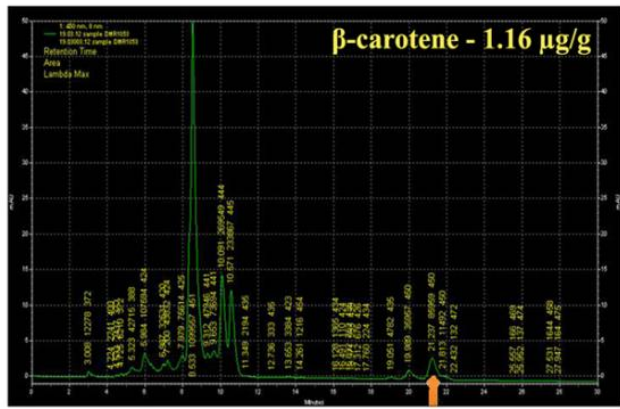

Retention time: $21.2 \mathrm{~min}$, Peak area: 85959 and Wavelength: $450 \mathrm{~nm}$

Figure.8 HPLC Chromatogram for $\beta$-carotene content of BC1F2 progeny [Pedigree: UMI 1200×HP467-15)-C15-S79]

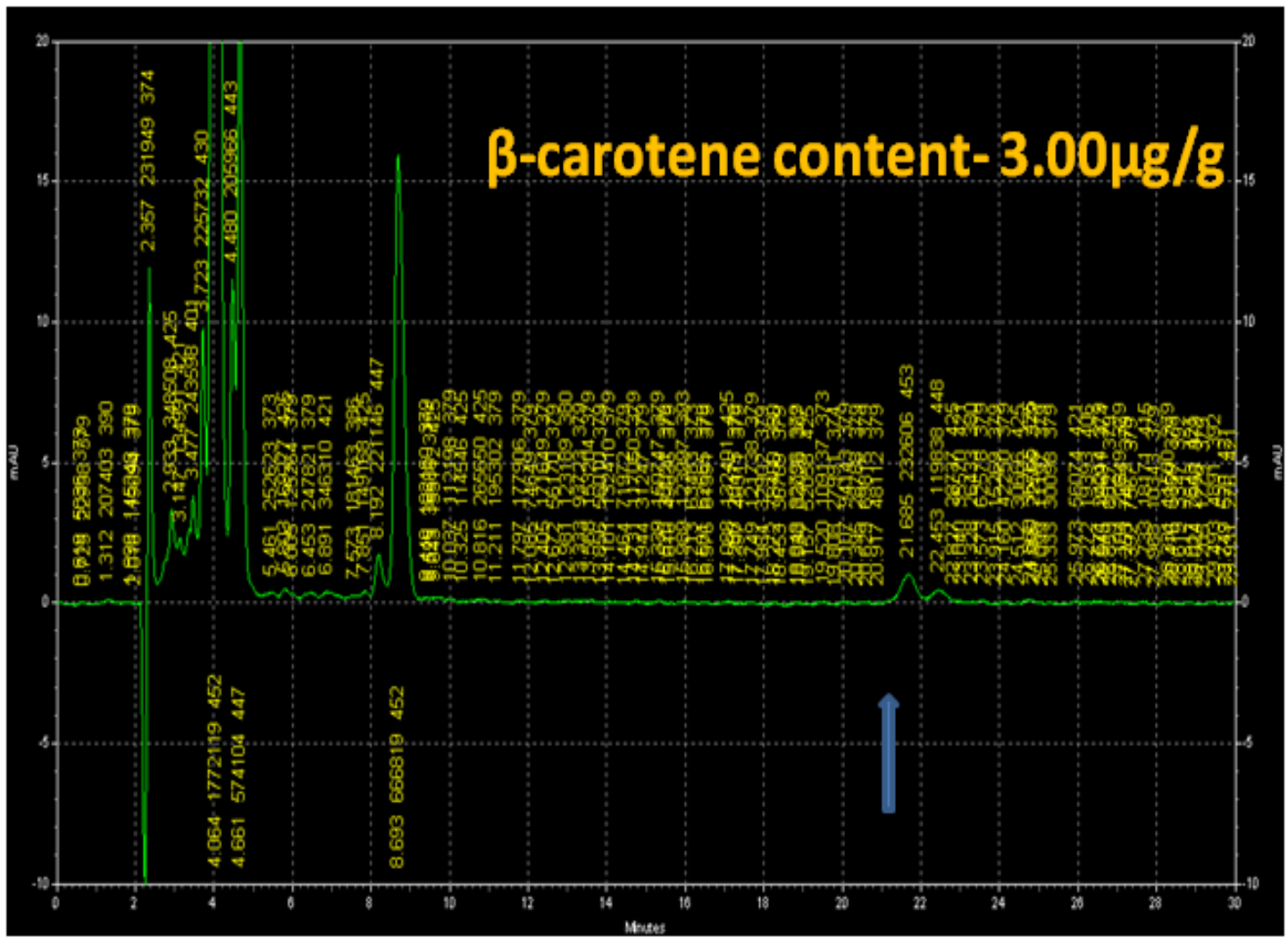

Retention time: $21.8 \mathrm{~min}$, Peak area: 232606 and Wavelength: $448 \mathrm{~nm}$

Performance of $\mathrm{BC}_{1} \mathrm{~F}_{2}$ generation of (UMI $1200 \times$ HP 467-15)-S15-S79

The $\mathrm{BC}_{1} \mathrm{~F}_{2}$ population (UMI $1200 \times \mathrm{HP} 467-$ 15)-S15-S79 progeny showed higher, range of variability for the traits viz., plant height (105$138 \mathrm{~cm}$ ) with mean value of $132.4 \mathrm{~cm}$ indicating the segregation of $\mathrm{BC}_{1} \mathrm{~F}_{2}$ progeny, while the days to 50 per cent tasseling ranged from 54-62 days with a mean value of 59 
days. Days to 50 per cent silking ranged from 57-64 days with a mean value of 61 days. The $\mathrm{BC}_{1} \mathrm{~F}_{2}$ progeny (UMI $1200 \times \mathrm{HP} 467-15$ )S15-S79 from the cross displayed maximum variance of 44.5 and 31 for plant height and ear height respectively (Table 3 ).

\section{Variability studies in (UMI $1200 \times$ HP 467- 15)-S15-S79 $\mathrm{BC}_{1} \mathrm{~F}_{2}$ segregating generation}

The values of various variability parameters pertaining to $\mathrm{BC}_{1} \mathrm{~F}_{2}$ segregating populations of the cross (UMI $1200 \times$ HP 467-15)-S15-S79 were presented (Table 4).

The percentage of PCV was less than 10 per cent (low variability) for days to 50 per cent tasseling $(4.40 \%)$, days to 50 per cent silking (3.2\%), plant height $(6.03 \%)$ and hundred kernel weight $(8.38 \%)$. PCV exhibited a moderate variability of 10-20 per cent for leaf length $(11.73 \%)$ and ear height $(11.91 \%)$. The percentage of GCV was less than 10 per cent (low variability) for days to 50 per cent tasseling (4.36\%), days to 50 per cent silking $(2.42 \%)$, plant height(5.93\%),ear height (4.3\%) and hundred kernel weight $(7.2 \%)$ while genotypic coefficient of variation exhibited a moderate variability (10-20\%) for leaf length (10.2\%).

These characters had moderate GCV and PCV which gives an indication of justifiable variability among the genotypes with respect to these characters and therefore gives scope for improvement of these traits in future generations through selection. The minor variation between values of $\mathrm{GCV}$ and $\mathrm{PCV}$ shows the limited role of environment in these characters and the heritability was very high for these traits. Similar results were reported by Bello et al., (2012).

The heritability estimates of $\mathrm{BC}_{1} \mathrm{~F}_{2}$ generation of the (UMI $1200 \times$ HP 467-15)-S15-S79 cross were found with highest heritability for plant height $(97.05 \%)$ while high heritability was found for hundred kernel weight(71.8\%),ear height $(66.07 \%)$ and leaf length $(64.4 \%)$. Days to $50 \%$ tasseling and silking was found to have medium heritability. Characters with high heritability could easily be fixed with simple selection resulting in quick progress. However, it had been accentuated that heritability alone had no practical importance without genetic advance (Najeeb et al., 2009).

Among the traits, highest genetic advance was exhibited for plant height (14.75). All other traits were found to have low genetic advance. High genetic advance coupled with high heritability estimates offers the most suitable condition for selection. This is the indication of predominance of additive gene action. This is desirable for selection since these are least influenced by the environment. Researchers (Rafique et al., 2004; Akbar et al., 2008; Rafiq et al., 2010) had reported that high heritability and high genetic advance for different yield controlling traits in maize. Therefore, availability of good knowledge of these genetic parameters existing in different yield contributing characters and the relative proportion of this genetic information in various quantitative traits is a pre-requisite for effective crop improvement.

The medium genetic advance as per cent of mean of 10-20 per cent was observed for plant height (12.04\%) and leaf length $(15.5 \%)$ while low genetic advance as per cent of mean of $<10$ per cent was observed for all other traits.

\section{Frequency distribution of (UMI $1200 \times \mathrm{HP}$ 467-15)-S15-S79 $\mathrm{BC}_{1} \mathrm{~F}_{2}$ population}

In (UMI $1200 \times$ HP 467-15)-S15-S79 cross $\mathrm{BC}_{1} \mathrm{~F}_{2}$ population (Figure 6 ), for the traits like plant height, ear height and 100 kernel weight, most of the progenies exhibited the values same as recurrent parent. For leaf length most of the progenies were found to 
possess values more than either parents. When traits like days to 50 per cent tasseling, days to 50 per cent silking are considered most of the progenies found to possess values less than either of parents.

Positive skewness was observed for traits like days to $50 \%$ tasseling, plant height and ear height. All other traits showed negative skewness (Table 5). The positive skewness indicates the presence of complementary epistatic gene action for the trait and the gain is slower with mild selection and gain is faster with intensive selection. The negative skewness indicates the presence of duplicate epistasis gene action and the gain is faster with mild selection and rapid with intense selection (Snape and Riggs, 1975).

Negative kurtosis (platykurtic curve) was observed for all the traits. The negative kurtosis indicate platykurtic curve which means that flat values are present in the distribution and complementary gene action. If selection for these characters were made intensively, the gain will be faster (Table 5).

Improvement in $\beta$-carotene content by introgression of favourable crtRB1 allele from exotic donor line (HP467-15) into popular inbred (UMI 1200) through marker assisted backcrossing

Both Recurrent (UMI 1200) and Donor (HP467-15) parents were analyzed for $\beta$ carotene content through HPLC and the results showed that UMI 1200 (Recurrent parent) has $\beta$-carotene content of $1.16 \mu \mathrm{g} / \mathrm{g}$ and HP467-15 (Donor parent) has $\beta$-carotene content of $5.1 \mu \mathrm{g} / \mathrm{g}$ (Figure 7). $\mathrm{BC}_{1} \mathrm{~F}_{2}$ showed confirmation of improvement in $\beta$-carotene content of $3.00 \mu \mathrm{g} / \mathrm{g}$ (UMI1200×HP467-15)C15-S79) (Figure 8). These were identified as promising bio-fortified lines and utilized for later generations (Table 6).
Thus the study of the evaluated populations indicated that it is possible to develop a high $\beta$-carotene inbred with genetic identity closer to that of the recurrent parent in latter generations.

In conclusion the present study was carried out to raise and identify high $\beta$ - carotene lines of $\mathrm{BC}_{1} \mathrm{~F}_{2}$ population by phenotyping using HPLC along with genotyping of crtRBl allele. As per the continuation of previous work the $\mathrm{BC}_{2} \mathrm{~F}_{1}$ and $\mathrm{BC}_{1} \mathrm{~F}_{2}$ seeds were collected by the ongoing GOI-DBT project "Marker assisted introgression of $L y c E$ gene for enhanced ProA in maize". The seeds of $\mathrm{BC}_{1} \mathrm{~F}_{2}$ progenies identified to contain high $\beta$ carotene by HPLC were raised to generate $\mathrm{BC}_{1} \mathrm{~F}_{2}$ population and field studies were carried. The crtRB1 allele specific foreground marker was used for identifying 543bp favorable allele in the segregating populations under evaluation.

The randomly selected 10 seeds of each selected $\mathrm{BC}_{1} \mathrm{~F}_{2}$ progenies were analyzed for $\beta$-carotene content through HPLC and the results showed confirmation of improvement in $\beta$-carotene content of $3.00 \mu \mathrm{g} / \mathrm{g}$ (i.e., up to 3 fold increase over the parent) and were identified as promising bio-fortified lines and utilized for later generations. The seeds of $\mathrm{BC}_{1} \mathrm{~F}_{2}$ progenies identified to contain high $\beta$ carotene by HPLC were raised to generate $\mathrm{BC}_{1} \mathrm{~F}_{2}(\mathrm{UMI} 1200 \times \mathrm{HP}$ 467-15)-C15-S79 population of 100 progenies out of which, 18 progenies were identified to be homozygous for favourable allele1 (546 bp). The crtRB1 allele polymorphism in $\mathrm{BC}_{1} \mathrm{~F}_{2}$ population of the cross revealed that the progenies showed segregation distortion (SD) i.e., deviation from the expected segregating ratio $\mathrm{BC}_{1} \mathrm{~F}_{2}$ $(1: 2: 1)$ populations, indicating that the favourable allele is under-represented in the population. The variability studies $\mathrm{BC}_{1} \mathrm{~F}_{2}$ populations of the crosses revealed that, the $\mathrm{BC}_{1} \mathrm{~F}_{2}$ population of $(\mathrm{UMI} 1200 \times \mathrm{HP} 467$ - 
15)-C15-S79, the percentage of PCV was less than 10 per cent (low variability) for days to 50 per cent tasseling $(4.40 \%)$, days to 50 per cent silking (3.2\%), plant height $(6.03 \%)$ and hundred kernel weight $(8.38 \%)$ The percentage of GCV was less than 10 per cent (low variability) for days to 50 per cent tasseling $(4.36 \%)$, days to 50 per cent silking $(2.42 \%)$, plant height $(5.93 \%)$, ear height (4.3\%) and hundred kernel weight (7.2\%). The heritability estimates of $\mathrm{BC}_{1} \mathrm{~F}_{2}$ generation of the (UMI $1200 \times \mathrm{HP} 467-15)-\mathrm{C} 15-\mathrm{S} 79$ cross were found with highest heritability for plant height $(97.05 \%)$ while high heritability was found for hundred kernel weight $(71.8 \%)$, ear height (66.07\%) and leaf length (64.4\%). Days to $50 \%$ tasseling and silking was found to have medium heritability. Among the traits, highest genetic advance was exhibited for plant height (14.75). All other traits were found to have low genetic advance. The medium genetic advance as per cent of mean of 10-20 per cent was observed for plant height (12.04\%) and leaf length (15.5\%) while low genetic advance as per cent of mean of $<10$ per cent was observed for all other traits

Frequency distribution study of $\mathrm{BC}_{1} \mathrm{~F}_{2}$ population states that for the traits like plant height, ear height, 100 kernel weight, most of the progenies exhibited the values same as or near to recurrent parent. The skewness obtained from the frequency distribution of the present study revealed that for (UMI 1200 $\times \mathrm{HP}$ 467-15)-C15-S79 $\mathrm{BC}_{1} \mathrm{~F}_{2}$ population, positive skewness was observed for traits like days to $50 \%$ tasseling, plant height and ear height. All other traits showed negative skewness. Negative kurtosis (platykurtic curve) was observed for all the six traits, in both $\mathrm{BC}_{2} \mathrm{~F}_{1}$ and $\mathrm{BC}_{1} \mathrm{~F}_{2}$ population.

Thus the variability studies of the evaluated populations indicated that it is possible to develop a high $\beta$-carotene inbred with genetic identity closer to that of the recurrent parent in latter generations. The study also revealed that information about the extent of variation, estimates of heritability and expected genetic advance in respect of maize grain yield and yield contributing characters constitutes the basic requirement for a crop improvement programme.

\section{References}

Ahmad, S.Q., S. Khan, M. Ghaffar and F. Ahmad. 2011. Genetic diversity analysis for yield and other parameters in maize (Zea mays L.) genotypes. Asian J. Agric. Sci., 3(5): 385-388

Akbar, M., M.S. Shakoor, A. Hussain and M. Sarwar. 2008. Evaluation of maize 3-way crosses through genetic variability, broad sense heritability, characters association and path analysis. J. Agric. Res., 46(1): 3945.

Babu, R., Rojas, N.P., Gao, S., Yan, J. and Pixley, K. 2012a. Validation of the effects of molecular marker polymorphisms in $L c y E$ and CrtRBI on provitamin A concentrations for 26 tropical maize populations. Theor. Appl. Gene., DOI 10.1007/s00122-012-19873.

Bello, O.B., S.A. Ige, M.A. Azeez, M.S. Afolabi, S.Y. Abdulmaliq and J. Mahamood. 2012. Heritability and Genetic Advance for Grain Yield and its 140 Component Characters in Maize (Zea Mays L.). Intl J. Pl. Res., 2(5): 138-145.

Dellaporta, S.L., J. Wood and J.B. Hicks. 1983. A plant DNA Mini preparation version 2. Plant Mol. Biol. Rep., 1: 19- 22.

Falconer, D.S. 1960. Introduction to Quantitative Genetics. Oliver and Boyd, Edinburgh. 340.

Johnson, D. and W. Russell. 1982. Genetic variability and relationships of physical grain-quality traits in the BSSS population of maize. Crop Sci., 22: 805-809.

Johnson, H.W., J.F. Robinson and R.E. Comstock. 1955. Estimates of genetic and environmental variability in soybean. Agron. J., 47: 314 - 318.

Laghari, K.A., M.A. Sial, M.A. A. Arain, A.A. Mirbahar, A.J. Pirzada, M.U. Dahot and 
S.M. Mangrio. 2010. Heritability studies of yield and yield associated traits in bread wheat. Pak. J. Bot., 42(1): 111-115.

Lu, H., J. Romero-Severson and R. Bernardo. 2002. Chromosomal regions associated with segregation distortion in maize. Theor. Appl. Genet., 105: 622-628.

Mangelsdorf, P.C. and D.F. Jones. 1926. The expression of Mendelian factors in the gametophyte of maize. Genetics, 11: 423455.

Najeeb, S., A.G. Rather, G.A. Parray, F.A. Sheikh and S.M. Razvi. 2009. Studies on genetic variability, genotypic correlation and path coefficient analysis in maize under high altitude temperate ecology of Kashmir. Maize Genetics Cooperation Newslett., 83: 1-8.

Netravati, G. Shantakumar, A. Sateesh, M. Laxman and G. Prakash. 2013. Heterosis Breeding for Maturity, Yield and Quality Characters in Maize (Zea mays L.). Mol. Pl. Breeding, 4(6): 44-49.

Neuffer, M.G., E.H. Coe and S.R. Wessler. 1997. Mutants of maize. Cold Spring Harbor Laboratory Press, USA

Rafiq, C.M., M. Rafique, A. Hussain and M. Altaf. 2010. Studies on heritability, correlation and path analysis in maize (Zea mays L.). $J$. Agric. Res., 48(1): 35-38.

Rafique, M., A. Hussain, T. Mahmood, A.W. Alvi and B. Alvi. 2004. Heritability and interrelationships among grain yield and yield components in maize (Zea mays L). Int. J. Agri. Biol., 6(6): 1113-1114.

Robinson, H.F., R.E. Comstock and P.H. Harvey. 1949. Estimates of heritability and the degree of dominance in corn. Agron. J., 41: $353-359$.

Sampoux, J.P., A. Gallais and M. Lefort-Buson.
1989. S1 value combined with topcross value for forage maize selection. Agronomie, 9: 5, 511-520.

Sivasubramanian, S. and P. Madhava Menon. 1973. Genotypic and phenotypic variability in rice. Madras Agric. J., 60: 1093 - 1096.

Snape, J.W and T.S. Riggs. 1975. Genetical consequences of single seed descent in the breeding of self pollinated crops. Heredity, 35: $211-219$.

Vallabhaneni, R., C.E. Gallagher, N. Licciardello, A.J. Cuttriss, R.F., Quinlan and E.T. Wurtzel. 2009. Metabolite sorting of a germplasm collection reveals the hydroxylase 3 locus as a new target for maize provitamin A biofortification. Plant Physiol., 151: 1635-1645.

Vignesh, M., Firoz Hossain, T. Nepolean, Supradip Saha, P.K. Agrawal, S.K. Guleria, B.M. Prasanna and H.S. Gupta. 2012. Genetic variability for kernel $\beta$-carotene and utilization of crtRB1 3'TE gene for biofortification in maize (Zea mays L.). Indian J. Genet., 72(2): 189-194.

Wang, X., Chang, J., Qin, G., Zhang, S., Cheng, X. and C. Li. 2011. Analysis on yield components of elite maize variety Xundan 20 with super high yield potential. Afr. $J$. Agric. Res., 6(24): 5490-5495.

Yan, J.B., C.B. Kandianis, C.E. Harjes, L. Bai, E.H. Kim, X.H. Yang, D.J. Skinner, Z.Y. $\mathrm{Fu}$, S. Mitchell, Q. Li, M.G. Fernandez, M. Zaharieva, R. Babu, Y. Fu, N. Palacios, J.S. Li, D. DellaPenna, T. Brutnell, E.S. Buckler, M.L. Warburton and T. Rocheford. 2010. Rare genetic variation at Zea mays crtRB1 increases B-carotene in maize grain. Nat. Genet., 42: 322-327.

\section{How to cite this article:}

Pitambara, P. Nagaraja and Senthil, N. 2017. Molecular Breeding and Variability Analysis of High Beta Carotene Introgressed $\mathrm{BC}_{1} \mathrm{~F}_{2}$ Line of Maize. Int.J.Curr.Microbiol.App.Sci. 6(4): 270-287. doi: https://doi.org/10.20546/ijcmas.2017.604.031 


\section{Annexure-I}

Foreground marker (crtRB1 3'TE) allelic polymorphism of (UMI $1200 \times$ HP467-15)-C15-S79 $\mathrm{BC}_{1} \mathrm{~F}_{2}$ population

\begin{tabular}{|c|c|c|c|c|c|}
\hline Progeny No. & Allele size (bp) & Progeny No. & Allele size (bp) & Progeny No. & Allele size (bp) \\
\hline 1 & 296 & 43 & 543 & 85 & $296+543$ \\
\hline 2 & 543 & 44 & 296 & 86 & 296 \\
\hline 3 & 296 & 45 & $296+543$ & 87 & 296 \\
\hline 4 & $296+543$ & 46 & 296 & 88 & 296 \\
\hline 5 & 543 & 47 & 543 & 89 & 543 \\
\hline 6 & 296 & 48 & $296+543$ & 90 & 296 \\
\hline 7 & 543 & 49 & 543 & 91 & 296 \\
\hline 8 & $296+543$ & 50 & $296+543$ & 92 & $296+543$ \\
\hline 9 & 543 & 51 & 296 & 93 & 296 \\
\hline 10 & $296+543$ & 52 & $296+543$ & 94 & 296 \\
\hline 11 & 296 & 53 & $296+543$ & 95 & 296 \\
\hline 12 & 543 & 54 & $296+543$ & 96 & $296+543$ \\
\hline 13 & 296 & 55 & 296 & 97 & $296+543$ \\
\hline 14 & $296+543$ & 56 & $296+543$ & 98 & $296+543$ \\
\hline 15 & 296 & 57 & 296 & 99 & 296 \\
\hline 16 & 543 & 58 & 296 & 100 & 296 \\
\hline 17 & $296+543$ & 59 & 296 & & \\
\hline 18 & 296 & 60 & $296+543$ & & \\
\hline 19 & $296+543$ & 61 & $296+543$ & & \\
\hline 20 & 543 & 62 & 296 & & \\
\hline 21 & $296+543$ & 63 & 296 & & \\
\hline 22 & $296+543$ & 64 & $296+543$ & & \\
\hline 23 & $296+543$ & 65 & $296+543$ & & \\
\hline 24 & 296 & 66 & 543 & & \\
\hline 25 & 296 & 67 & 543 & & \\
\hline 26 & 543 & 68 & $296+543$ & & \\
\hline 27 & $296+543$ & 69 & 296 & & \\
\hline 28 & 296 & 70 & $296+543$ & & \\
\hline 29 & $296+543$ & 71 & $296+543$ & & \\
\hline 30 & 296 & 72 & 296 & & \\
\hline 31 & 296 & 73 & $296+543$ & & \\
\hline 32 & 296 & 74 & 543 & & \\
\hline 33 & $296+543$ & 75 & $296+543$ & & \\
\hline 34 & 296 & 76 & 296 & & \\
\hline 35 & 296 & 77 & $296+543$ & & \\
\hline 36 & 296 & 78 & 296 & & \\
\hline 37 & 296 & 79 & 543 & & \\
\hline 38 & 543 & 80 & 296 & & \\
\hline 39 & 543 & 81 & 296 & & \\
\hline 40 & $296+543$ & 82 & $296+543$ & & \\
\hline 41 & $296+543$ & 83 & 296 & & \\
\hline 42 & 296 & 84 & $296+543$ & & \\
\hline \multicolumn{6}{|c|}{ Allele type 'AA' - 296 bp; $\quad$ Allele type 'BB'- 543 bp; } \\
\hline
\end{tabular}

